\title{
KARAKTERISTIK STRUKTUR GEOLOGI DAN PERANANNYA TERHADAP SISTEM PANAS BUMI NAGE, KABUPATEN NGADA, PROVINSI NUSA TENGGARA TIMUR
}

\section{STRUCTURAL GEOLOGY CHARACTERISTICS AND ITS ROLES TO THE NAGE GEOTHERMAL SYSTEM, NGADA DISTRICT, EAST NUSA TENGGARA PROVINCE}

\author{
Devito Pradipta ${ }^{1}$, Lano Adhitya Permana ${ }^{2}$, dan Divi Muhammad Ramdhan ${ }^{3}$ \\ ${ }^{1}$ Program Studi Magister Teknik Geologi, Fakultas Ilmu dan Teknologi Kebumian, \\ Institut Teknologi Bandung \\ ${ }^{2}$ Pusat Sumber Daya Mineral Batubara dan Panas Bumi \\ ${ }^{3} \mathrm{PT}$ Nata Terra Resources \\ 22020308@mahasiswa.itb.ac.id
}

\begin{abstract}
ABSTRAK
Daerah Nage merupakan bagian dari jalur vulkanisme Busur Sunda-Banda yang membentuk rangkaian en-echelon di Pulau Flores. Tatanan tektonik regional di Pulau Flores yang cukup kompleks menyebabkan adanya struktur geologi yang intensif di daerah penelitian. Metode penelitian yang digunakan meliputi pengamatan struktur geologi melalui analisis kelurusan topografi, kelurusan sungai, fitur melingkar dan densitas kelurusan (fracture fault density) dengan menggunakan citra DEMNAS serta pengukuran secara langsung di lapangan terhadap unsur-unsur struktur geologi primer dan sekunder pada 87 stasiun pengamatan. Pengukuran terhadap 441 kedudukan struktur geologi di daerah penelitian, menunjukkan bahwa struktur geologi sekunder, utamanya berupa kekar gerus, yang berguna untuk membuktikan kehadiran sesar yang memotong batuan berumur Kuarter pada daerah penelitian. Hasil analisis kinematika menyimpulkan bahwa terdapat sesar geser oblik berarah baratlaut-selatan tenggara dan timurlaut-baratdaya serta sesar geser berarah timur laut-baratdaya. Daerah penelitian terdapat fitur melingkar yang berasosiasi dengan peruntuhan kaldera dan pembentukan kawah. Analisis dinamik sesar untuk menentukan arah tegasan kompresif menunjukkan bahwa daerah penelitian mengalami deformasi kompresional berarah utara

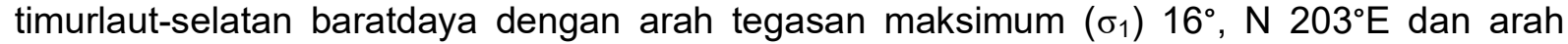
tegasan minimum $\left(\sigma_{3}\right) 17,5^{\circ}, \mathrm{N} 297,1^{\circ} \mathrm{E}$. Keberadaan struktur sesar diinterpretasikan memiliki peran sebagai jalur fluida terhadap sistem panas bumi Nage yang tampak dari kehadiran manifestasi panas bumi dan alterasi hidrotermal. Berdasarkan konfigurasi sesar, manifestasi, dan alterasi hidrotermal disimpulkan bahwa setidaknya terdapat tiga aliran fluida, yakni aliran fluida hidrotermal yang naik melalui sesar F1 dan dibatasi sesar F3, aliran fluida yang naik melalui sesar F2, dan aliran fluida hasil pendidihan yang naik melalui F10.
\end{abstract}

Kata kunci: analisis kinematika, analisis dinamik, alterasi hidrotermal, permeabilitas, Nage

\section{ABSTRACT}

Nage Region is part of Sunda-Banda Arc volcanism which formed an en-echelon array in Flores Island. The complex regional tectonics setting of the study area has created intensively found geological structures in the study area. The study was made through identification of structural geology by topographic lineament analysis, river lineament, circular features, and fault fracture density in DEMNAS image and followed by field observation to identify primary and secondary geological structures in 87 stations. The measurements of 441 geological structures positions in the study area found that secondary geological structures, mainly shear fractures, in order to identify the occurence of minor faults which are found in Quarternary rocks in the study area. Kinematic analysis of minor faults confirms the occurence of NW-SE 
and NE-SW oblique strike slip faults and also NE-SW directed strike slip fault. Normal faults in the study area are ffound as circular features which has been formed and associated with caldera collapse and crater forming processes. Dynamic analyses of faults are conducted to determine the principle compressive stress orientation which formed the faults has concluded that the compressional regime of the study area occured in the NNE-SSW direction with maximum stress $\left(\sigma_{1}\right)$ direction is $16^{\circ}, N 203^{\circ} \mathrm{E}$ and minimum stress $\left(\sigma_{3}\right)$ direction is $17,5^{\circ}, \mathrm{N}$ $297,1^{\circ} \mathrm{E}$. Faults are interpreted to have roles as fluid pathway in the developing geothermal system based on the occurence of hotspring manifestation and hydrothermal alteration. Based on the configuration of faults, geothermal manifestation, and hydrothermal alteration, it can be concluded that there are at least three fluid flow in the study area which are correlated with hydrothermal fluid ascent through fault $F 1$ and bounded by fault $F 3$, hydrothermal fluid ascent through fault $F 2$, and hydrothermal fluid ascent from boiling through fault F10.

Keywords: kinematic analysis, dynamic analysis, hydrothermal alteration, permeability, Nage.

\section{PENDAHULUAN}

Pulau Flores merupakan busur vulkanik yang membentuk jajaran gunung api dengan rangkaian en echelon sebagai jalur vulkanisme Busur Sunda-Banda (Muraoka dkk., 2002). Tatanan tektonik daerah penelitian menghasilkan aktivitas vulkanisme berumur Tersier hingga Kuarter. Daerah penelitian terletak di lapangan panasbumi Nage, Kabupaten Ngada, Provinsi Nusa Tenggara Timur, tepat di sebelah timur Gunung Api Inirie (Gambar 1). Aktivitas vulkanisme di daerah Nage menimbulkan pembentukan sistem panas bumi yang diinterpretasikan berasal dari aktivitas vulkanisme pasca kaldera Nage, yaitu Wolo Piu dan Bena yang berumur Kuarter (Anonim, 2017). Fluida hidrotermal dari sumber panas yang diduga terdapat di bawah Nage dan Keli akan naik menuju ke permukaan melalui struktur yang berperan sebagai rekahan. Fluida hidrotermal yang telah keluar mencapai permukaan membentuk manifestasi panas bumi berupa mata air panas dan alterasi hidrotermal yang merupakan produk reaksi berupa proses hidrolisis dan leaching antara fluida dengan batuan samping (Pirajno, 2009).

Deformasi batuan di kerak bumi dapat berlangsung pada kondisi brittle, ductile, atau transisi keduanya. Deformasi yang berlangsung pada kondisi brittle akan membentuk rekahan. Rekahan tersebut dapat terbentuk pada deformasi kompresif, tarikan (tensile), atau keduanya (hybrid). Rekahan yang terbentuk dapat berupa kekar gerus dan kekar tarik. Kekar tarik yang terisi oleh material umum disebut urat dan yang terisi oleh magma dapat hadir sebagai korok atau gang (Fossen, 2016). Sesar dan rekahan dapat hadir sebagai jalur naiknya fluida dalam sistem panas bumi. Zona sesar yang berada dalam area interaksi sesar merupakan jalur permeabilitas konduktif terbaik dalam kenaikan fluida (Fauldz dan Hinz, 2015). Sesar merupakan rekahan yang terbentuk dari deformasi brittle sebagai diskontinuitas pada tubuh batuan yang menunjukkan adanya pergeseran. Pembentukan sebuah sesar diikuti dengan kehadiran struktur penyerta berupa kekar gerus, kekar tarik, dan lipatan minor pada zona hancuran sesar (Moody dan Hill, 1956; Fossen, 2016).

Keberadaan sesar merupakan indikasi penting yang dapat menjelaskan keberadaan anomali geokimia, alterasi, dan bidang lemah. Identifikasi sesar diperlukan untuk menentukan sesar yang menjadi zona permeabel dan yang tidak berpengaruh sebagai pertimbangan eksplorasi lapangan panas bumi lebih lanjut, seperti pengeboran dan lintasan survey geofisika. Penelitian ini bertujuan untuk mengindentifikasi keberadaan struktur geologi yang ditemukan di lapangan panas bumi Nage yang memiliki peran sebagai jalur permeabel fluida pada sistem panas bumi Nage. 


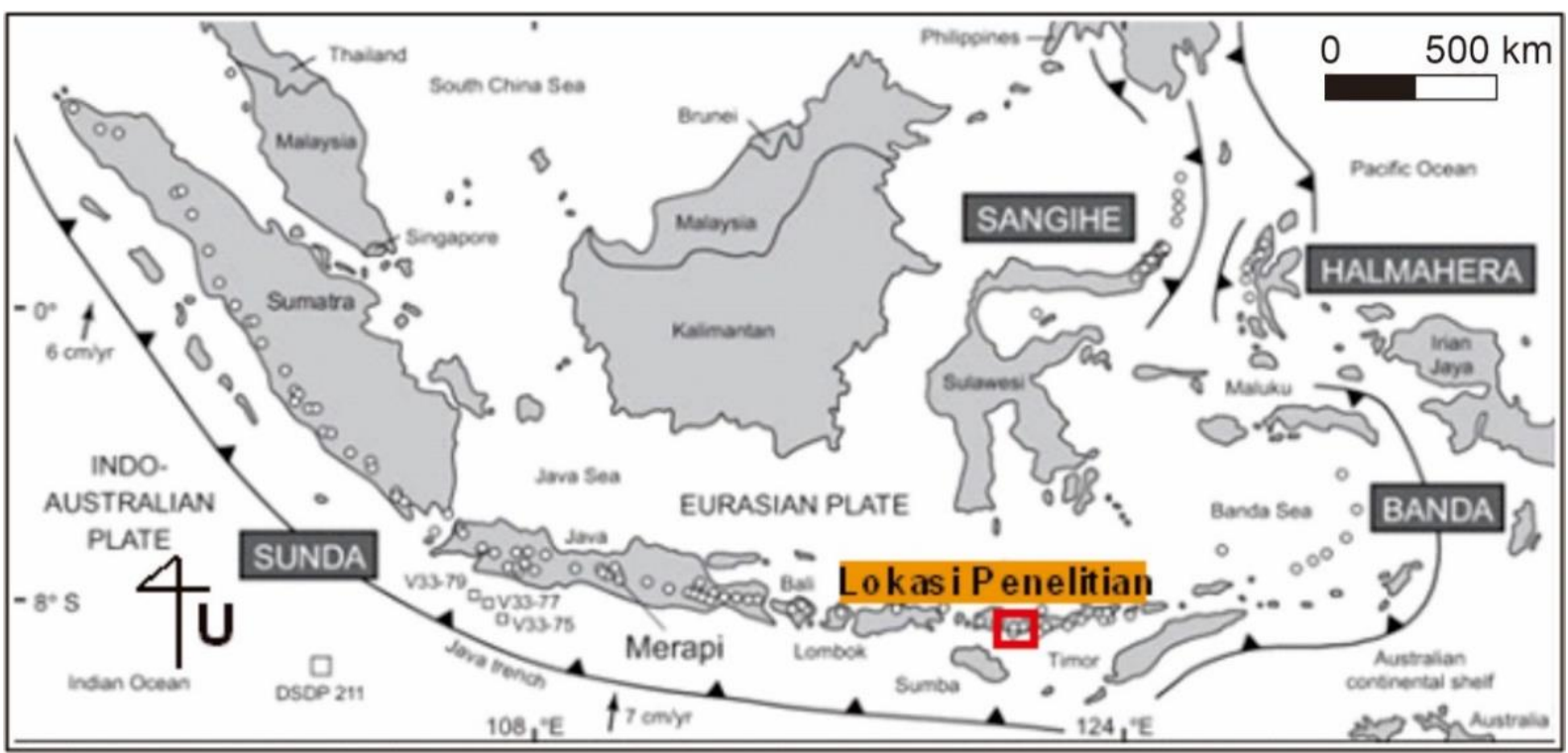

Gambar 1. Tatanan tektonik lokasi penelitian pada Busur Sunda-Banda (Hamilton, 1979)

\section{METODOLOGI}

Penelitian ini dilakukan melalui pengamatan citra DEMNAS untuk mengidentifikasi kelurusan topografi, kelurusan sungai, fitur melingkar dan densitas kelurusan dari yang diduga sebagai adanya keberadaan struktur di permukaan. Pengamatan struktur turut dilakukan dengan observasi lapangan secara langsung, yaitu melalui pemetaan vulkanostratigrafi dan pemetaan struktur. Pemetaan vulkanostratigrafi dilakukan untuk mengetahui endapan vulkanisme di daerah penelitian serta urutan-urutan pembentukannya. Pemetaan struktur geologi dilakukan dengan pengamatan struktur primer dan sekunder pada 87 stasiun. Kedudukan struktur geologi yang diamati berupa jurus, kemiringan, trend, plunge, dan pitch dari setiap unsur struktur.

Pengolahan data struktur geologi dilakukan dengan menggunakan perangkat lunak Dips 7.0 untuk analisis kinematika dan Faultkin 8.1.1 untuk pengolahan analisis dinamik. Pada analisis kinematika, kedudukan kutub setiap populasi struktur dibuat kontur sesuai dengan metode Kamb (1959) untuk memperoleh distribusi dan orientasi maksimal kedudukan populasi struktur. Analisis dinamik, dilakukan untuk menentukan sumbu kinematika $P$ dan $T$ yang diperoleh dari perpotongan bidang sesar terhadap konjugatnya. Sumbu kinematika $\mathrm{P}$ dan $\mathrm{T}$ terletak di sepanjang bidang pergerakan sesar (movement plane I $m$ plane) dengan kutub dari bidang tersebut terletak pada perpotongan bidang sesar dengan konjugat sesar, seperti yang tampak pada Gambar 2 (Marett dan Almendinger, 1990).

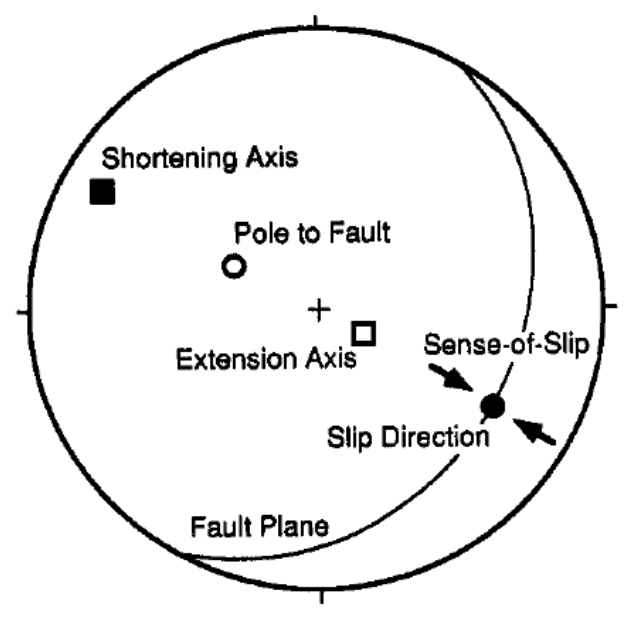

Gambar 2. Geometri analisis kinematika dan dinamik sesar pada stereonet

Menurut Sapiie (2016), analisis dinamik dilakukan dengan asumsi bahwa deformasi terjadi pada kondisi homogen dan isotropi. Analisis dinamik dilakukan sebagai pendekatan dalam identifikasi arah tegasan yang membentuk sesar di daerah penelitian dengan menggunakan data kedudukan pergerakan sesar dari hasil analisis kinematika. Hal tersebut menjadi batasan 
penelitian pada daerah penelitian dengan deformasi yang berlangsung pada kondisi heterogen dan anisotropi.

\section{GEOLOGI}

Pulau Flores terletak pada Blok Sundaland dan berada di perbatasan antara Lempeng Eurasia dan Indo-Australia. Interaksi Lempeng Eurasia dan Indo-Australia ditandai dengan subduksi Busur Sunda di sebelah barat dan Busur Banda di bagian timur dengan kerak samudera IndoAustralia menunjam ke bawah Lempeng Eurasia. Berdasarkan pengamatan GPS, Blok Indo-Australia bergerak relatif ke arah utara timurlaut menuju Lempeng Eurasia (Kreemer dkk., 2000) sehingga menyebabkan rotasi berlawanan arah jarum jam pada Pulau Flores. Rotasi tersebut menyebabkan terbentuknya rangkaian gunung api berbentuk enechelon pada Pulau Flores (Muraoka dkk., 2005), salah satunya pada daerah Nage (Gambar 3).

Berdasarkan penelitian yang dilakukan oleh Koesoemadinata dkk. (1994) dan Muraoka dkk. (2002), daerah Nage terdiri dari batuan vulkanik yang berumur Tersier hingga Kuarter. Batuan vulkanik yang terdapat di daerah penelitian diperkirakan berasal dari produk erupsi tujuh kerucut gunung api, diantaranya yaitu Wolo Kenowe, Wolo Deru, Wolo Batulaba, Wolo Piu, Bena, Kerucut Sinder dan Gunung Inirie (Gambar 4). Secara umum, jenis batuan vulkanik yang terdapat di daerah Nage tersusun atas lava, aliran piroklastik, jatuhan piroklastik dan endapan alluvial. Lava memiliki komposisi andesitik, bertekstur porfiritik hingga afanitik, di beberapa tempat dijumpai telah mengalami ubahan menjadi mineral lempung dan terdapat struktur kekar kolom serta kekar berlembar. Aliran piroklastik berkomposisi andesitik, terkonsolidasi baik dan memiliki sortasi buruk dengan bentuk menyudut hingga menyudut tanggung. Sedangkan, jatuhan piroklastik di daerah Nage memiliki komponen berupa tuff, litik andesit dan skoria dengan bentuk menyudut menyudut tanggung serta memiliki ketebalan sekitar 3 hingga $20 \mathrm{~cm}$.

Selain batuan vulkanik, pada daerah penelitian dijumpai adanya alterasi hidrotermal yang mengalami intensitas alterasi sedang hingga kuat berupa mineral lempung yang terdapat di sekitar manifestasi fumarol di Wolo Puti, mata air panas Keli, mata air panas Nage dan dinding utara serta timur dari Kaldera.

Struktur geologi di daerah penelitian teramati pada citra DEMNAS yang terindikasi berupa fitur melingkar sebagai kaldera dan kawah, adanya kelurusan kerucut sinder yang relatif berarah utara selatan serta hasil observasi lapangan yang menunjukkan adanya struktur penyerta dan zona hancuran yang mengindikasikan struktur sesar geser yang relatif berarah timurlaut-barat daya dan baratlaut-tenggara. Keberadaan struktur tersebut diduga mempengaruhi kemunculan manifestasi panas bumi di daerah Nage.

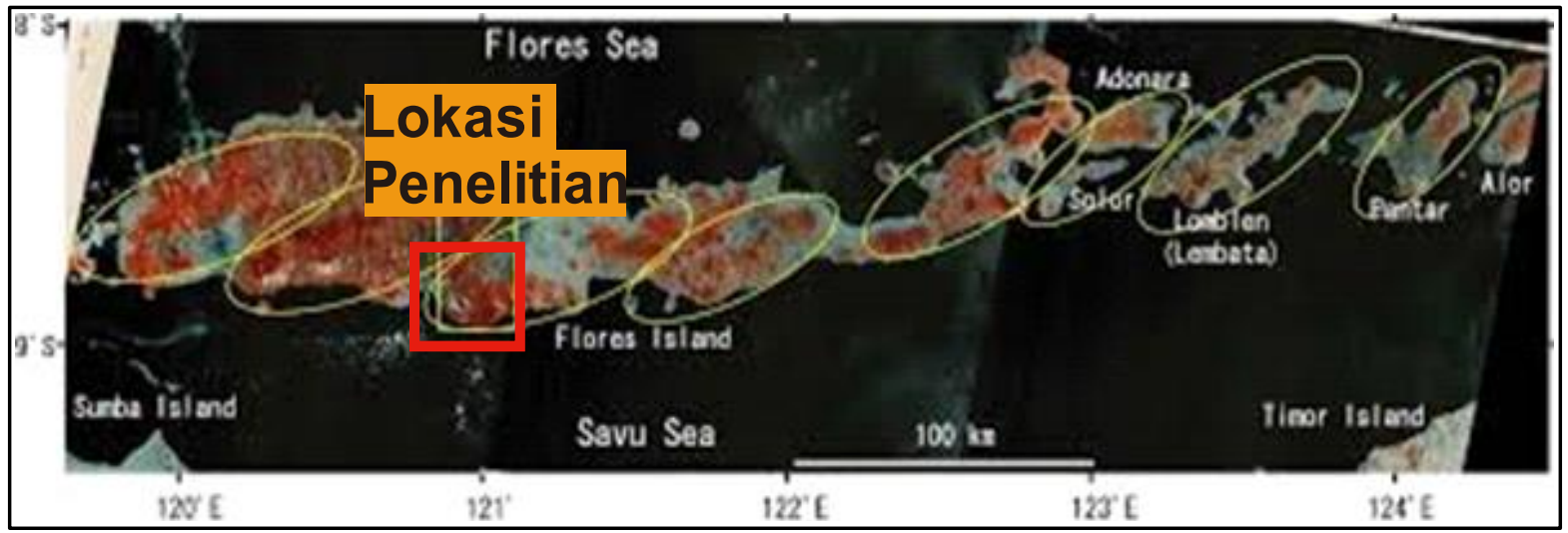

Gambar 3. Rangkaian topografi en-echelon pada Pulau Flores (Muraoka dkk., 2002) 


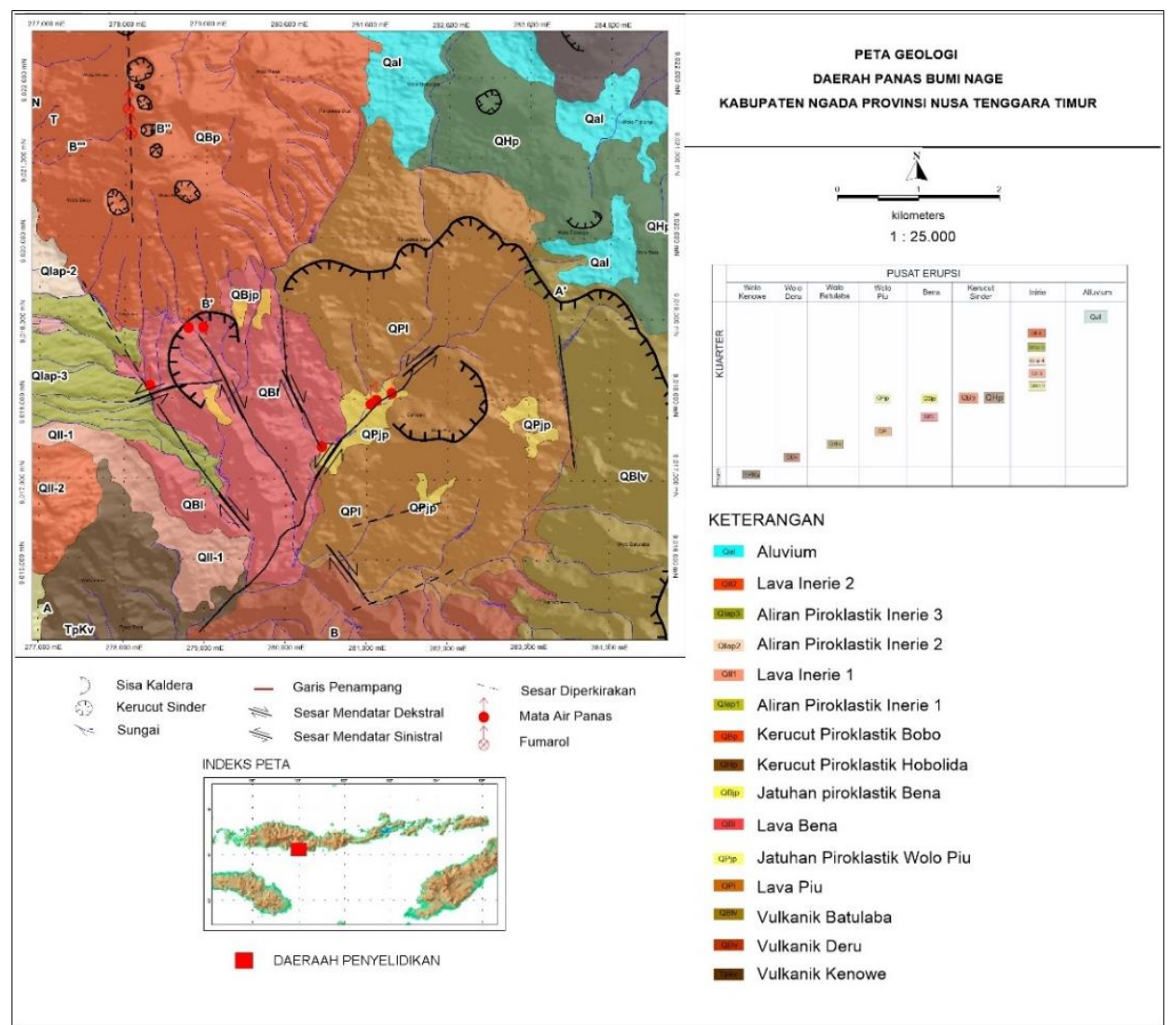

Gambar 4. Peta geologi hasil observasi lapangan daerah penelitian (modifikasi setelah Anonim, 2017)

\section{HASIL DAN PEMBAHASAN}

\section{HASIL}

Penelitian ini telah meninjau keberadaan struktur geologi di daerah penelitian berdasarkan citra satelit dan observasi lapangan untuk analisis kinematika, dinamika, serta implikasinya terhadap lapangan panas bumi Nage. Struktur primer ditemukan berupa kekar kolom, kekar berlembar, dan kontak litologi sebagai produk aliran vulkanisme. Struktur sekunder ditemukan berupa sesar geser oblik mengiri normal Nage bernotasi F1, sesar geser oblik menganan normal Leko Laka bernotasi F2, sesar geser oblik menganan naik Wae Roa bernotasi $\mathrm{F} 3$, sesar geser oblik menganan $\mathrm{N} 20^{\circ} \mathrm{E}-\mathrm{N} 30^{\circ} \mathrm{E}$, dan $\mathrm{N} 320^{\circ} \mathrm{E}-\mathrm{N} 330^{\circ} \mathrm{E}$ (Gambar 5). Kelurusan pada daerah penelitian diolah untuk membuat densitas kelurusan (fault fractures density) dengan grid 30 x $30 \mathrm{~m}$. Anomali densitas kelurusan pada daerah penelitian berasosiasi dengan manifestasi air panas, alterasi hidrotermal normal Jerebu'u bernotasi F4, sesar geser oblik menganan normal Wae Nanga bernotasi F5, sesar geser mengiri Bena bernotasi F6, dan sesar geser oblik menganan normal Gurusina bernotasi F7. Pada observasi citra DEMNAS, terdapat beberapa kelurusan diskontinuitas permukaan (sesar bernotasi F8 dan F9) dan kelurusan kerucut sinder yang diduga sebagai struktur sesar bernotasi F10. Secara ringkas, sebaran struktur yang terdapat di daerah survei ditampilkan pada Gambar 10.

Berdasarkan penarikan kelurusan yang dibuat pada citra DEMNAS, kelurusan di daerah penelitian terdapat beberapa arah umum yakni $\mathrm{N} 50^{\circ} \mathrm{E}-\mathrm{N} 60^{\circ} \mathrm{E}, \mathrm{N} 100-110^{\circ} \mathrm{E}$, yang intensif, dan keberadaan sesar di daerah penelitian (Gambar 6).

Sesar F1 berarah timurlaut-baratdaya yang memanjang di Wae Bana hingga Jerebuu. Sesar F1 dicirikan dengan diskontinuitas permukaan di citra, kelurusan sungai, dan 


\section{MAKALAH ILMIAH}

depresi topografi. Analisis kinematika sesar F1 menunjukkan bidang sesar berkedudukan $\mathrm{N} 217^{\circ} \mathrm{E} / 58^{\circ}$. Struktur penyerta berupa kekar gerus dengan kedudukan N $327^{\circ} \mathrm{E} / 52^{\circ}$ dan N $224^{\circ} \mathrm{E} / 53^{\circ}$. Berdasarkan analisis kinematika, sesar ini bergerak oblik mengiri normal dengan arah tegasan utama $50^{\circ}, \mathrm{N} 177^{\circ} \mathrm{E}$. Zona hancuran sesar ini berasosiasi dengan keberadaan manifestasi mata air panas Nage 1 dan Nage 2, alterasi hidrotermal mineral lempung yang intensif, dan struktur penyerta dalam jumlah intensif.

Sesar F2 berarah utara baratlaut-selatan tenggara yang memanjang dari kerucut sinder di utara hingga tepi sungai Jerebuu. Sesar F2 dicirikan dengan diskontinuitas permukaan di citra dan depresi topografi. Analisis kinematika sesar F2 menunjukkan bidang sesar berkedudukan $\mathrm{N} 156^{\circ} \mathrm{E} / 76^{\circ}$. Struktur penyerta berupa kekar gerus dengan kedudukan $\mathrm{N} 145^{\circ} \mathrm{E} / 68^{\circ}$ dan $\mathrm{N}$ $38^{\circ} \mathrm{E} / 61^{\circ}$. Sesar ini bergerak oblik menganan normal dengan arah tegasan utama $68^{\circ}, \mathrm{N} 001^{\circ} \mathrm{E}$ berdasarkan analisis kinematika. Sesar ini searah dengan kelurusan kerucut sinder dan sungai berarah baratlaut-tenggara. Zona hancuran sesar ini berasosiasi dengan keberadaan manifestasi mata air panas Keli 1 dan fumarol Wolo Puti serta alterasi hidrotermal mineral lempung yang intensif.
Sesar F3 berarah utara baratlaut-selatan tenggara yang memanjang Wae Roa hingga Malabhaga. Sesar F3 dicirikan dengan diskontinuitas permukaan di citra dan kelurusan sungai. Analisis kinematika sesar F3 menunjukkan bidang sesar berkedudukan $\mathrm{N} 343^{\circ} \mathrm{E} / 63^{\circ}$. Struktur penyerta berupa kekar gerus dengan kedudukan $\mathrm{N} 346^{\circ} \mathrm{E} / 62^{\circ}$ dan $\mathrm{N} 49^{\circ} \mathrm{E} / 68^{\circ}$. Sesar ini bergerak oblik menganan naik dengan arah tegasan utama $9^{\circ}, \mathrm{N} 347^{\circ} \mathrm{E}$ berdasarkan analisis kinematika. Zona hancuran sesar ini berasosiasi alterasi hidrotermal mineral lempung yang intensif dan struktur penyerta dalam jumlah intensif.

Sesar F4 berarah baratlaut-tenggara yang berada di Sungai Jerebuu. Sesar F4 dicirikan dengan kelurusan sungai. Analisis kinematika sesar F4 menunjukkan bidang sesar berkedudukan $\mathrm{N} 332^{\circ} \mathrm{E} / 63^{\circ}$. Struktur penyerta berupa kekar gerus dengan kedudukan $\mathrm{N} 34^{\circ} \mathrm{E} / 64^{\circ}$ dan $\mathrm{N} 335^{\circ} \mathrm{E} / 62^{\circ}$. Sesar ini bergerak oblik menganan naik dengan arah tegasan utama $1^{\circ}, \mathrm{N} 182^{\circ} \mathrm{E}$ berdasarkan analisis kinematika. Zona hancuran sesar ini berasosiasi alterasi hidrotermal mineral lempung yang intensif secara setempat, struktur penyerta dalam jumlah intensif, dan kemunculan air panas di sungai sebagai rekahan di sungai.
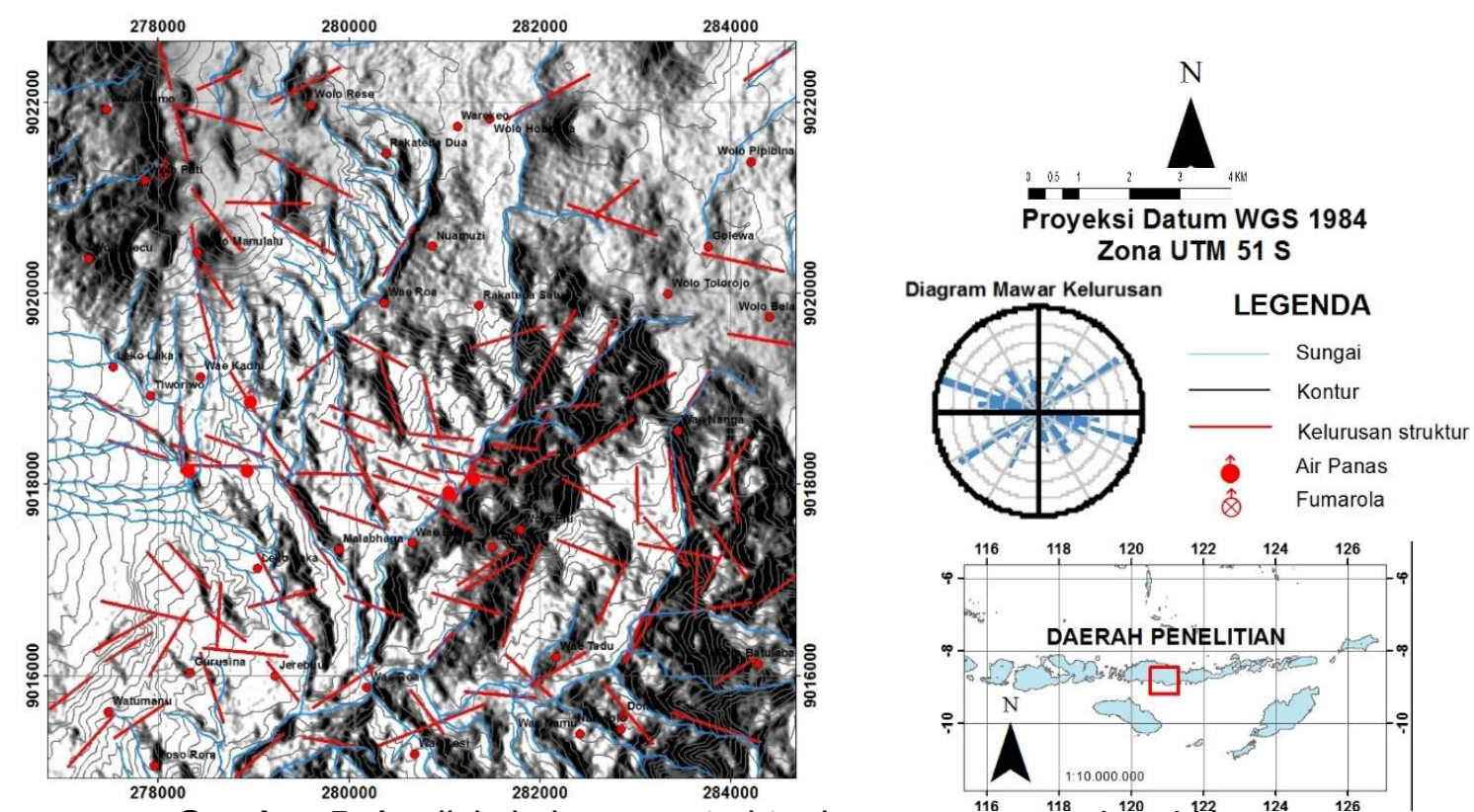

Gambar 5. Analisis kelurusan struktur lapangan panas bumi ${ }^{112}{ }^{121}{ }^{120} e^{124}$ 
Sesar F5 berarah utara baratlaut-selatan tenggara yang berada di Sungai Wae Nanga. Sesar F5 dicirikan dengan kelurusan sungai Wae Nanga. Analisis kinematika sesar F5 menunjukkan bidang sesar berkedudukan $\mathrm{N} 354^{\circ} \mathrm{E} / 80^{\circ}$. Struktur penyerta berupa kekar gerus dengan kedudukan N $211^{\circ} \mathrm{E} / 667^{\circ}$ dan N $330^{\circ} \mathrm{E} /$ $62^{\circ}$. Sesar ini bergerak oblik menganan normal dengan arah tegasan utama $44^{\circ}, \mathrm{N}$ $177^{\circ} \mathrm{E}$ berdasarkan analisis kinematika. Zona hancuran sesar ini berasosiasi alterasi hidrotermal mineral lempung yang intensif dan struktur penyerta dalam jumlah intensif. Analisis kinematika sesar dan kamb contour kekar gerus ditunjukkan pada Gambar 7.

Sesar F6 berarah timurlaut-baratdaya yang memanjang di Bena. Zona hancuran sesar ini berasosiasi dengan keberadaan manifestasi mata air panas Nage 1 dan Nage 2, alterasi hidrotermal mineral lempung yang intensif, dan struktur penyerta dalam jumlah intensif. Sesar F5 berkedudukan $\mathrm{N} 250^{\circ} \mathrm{E} / 45^{\circ}$ dan diinterpretasikan sebagai sesar orde ke-dua dari sesar F1.

Sesar F7 berarah utara baratlaut-selatan tenggara yang berada di Sungai Leko Laka hingga Gurusina. Sesar F7 dicirikan dengan kelurusan diskontinuitas permukaan pada citra DEMNAS. Analisis kinematika sesar F7 menunjukkan adanya bidang sesar yang berkedudukan $\mathrm{N} 319^{\circ} \mathrm{E} / 60^{\circ}$. Struktur penyerta berupa kekar gerus dengan kedudukan $\mathrm{N} 337^{\circ} \mathrm{E} / 55^{\circ}$ dan $\mathrm{N} 40^{\circ} \mathrm{E} / 63^{\circ}$. Sesar ini bergerak oblik menganan normal dengan arah tegasan utama $03^{\circ}, \mathrm{N} 178^{\circ} \mathrm{E}$ berdasarkan analisis kinematika. Zona hancuran sesar ini berasosiasi kehadiran manifestasi mata air panas Bena. Analisis kinematika sesar dan kamb contour kekar gerus ditunjukkan pada Gambar 7 .

Arah tegasan utama masing-masing sesar ditentukan berdasarkan analisis kinematika (Tabel 1) dan didukung dengan analisis dinamik. Arah tegasan relatif umum daerah penelitian berarah relatif utara timurlautselatan baratdaya. $P$-axis pada daerah penelitian didapat $12,6^{\circ}, \mathrm{N} 203^{\circ} \mathrm{E}$ dan $T$-axis berkedudukan $17,5^{\circ}, \mathrm{N} 297,1^{\circ} \mathrm{E}$ (Gambar 8). Magnitudo relatif setiap sumbu strain pada daerah penelitian dinyatakan dalam eigenvalue, yakni $\mathrm{e}_{1}$ sebesar 0,3982, $\mathrm{e}_{2}$ sebesar 0,0073 , dan $e_{3}$ sebesar 0,3910 berdasarkan pengolahan analisis dinamik oleh perangkat lunak Faultkin.

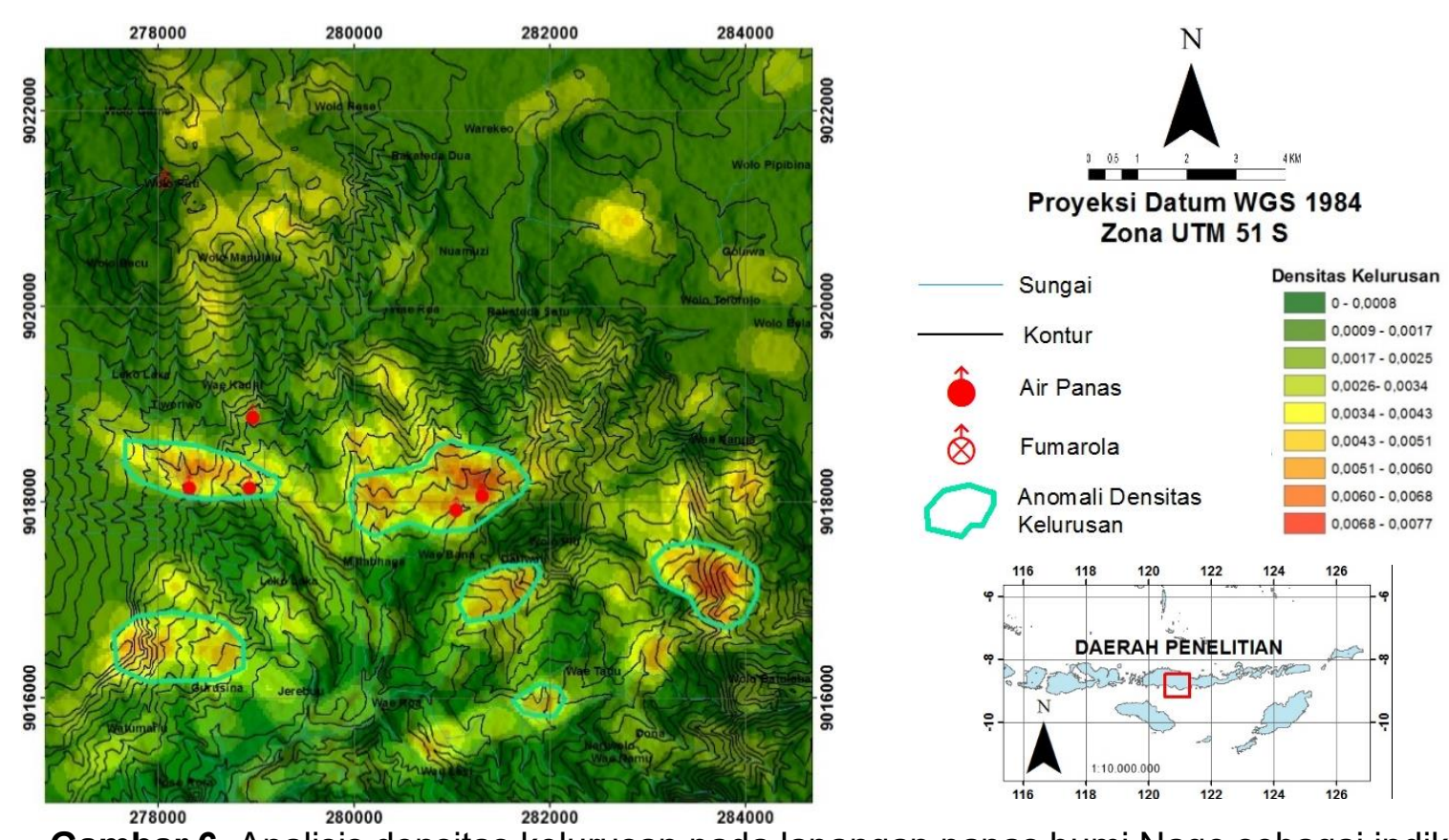

Gambar 6. Analisis densitas kelurusan pada lapangan panas bumi Nage sebagai indikasi keberadaan struktur geologi dan bidang lemah 


\section{MAKALAH ILMIAH}

F1
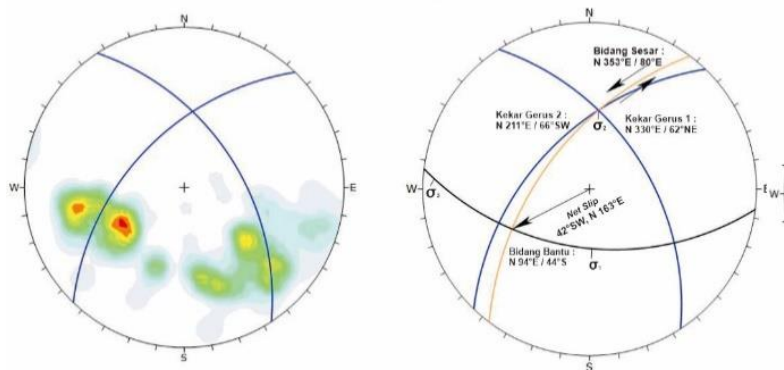

F3

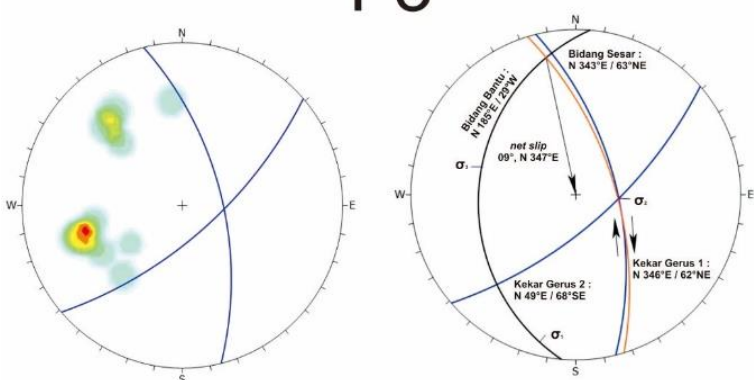

F5
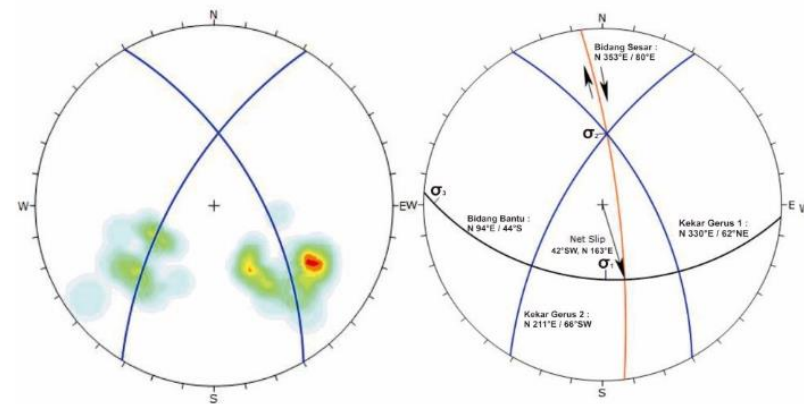

F2

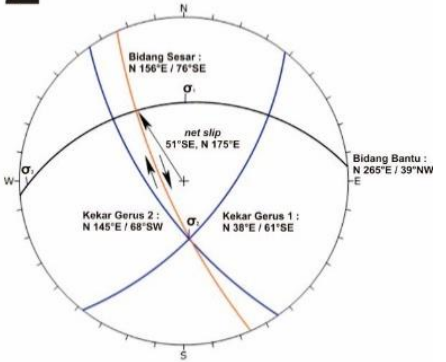

F4

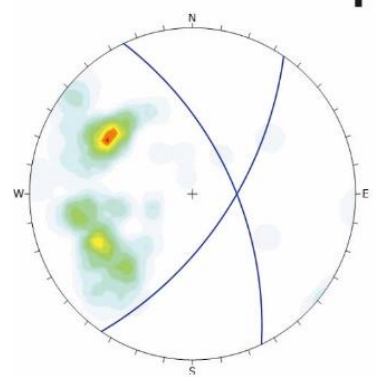

F7

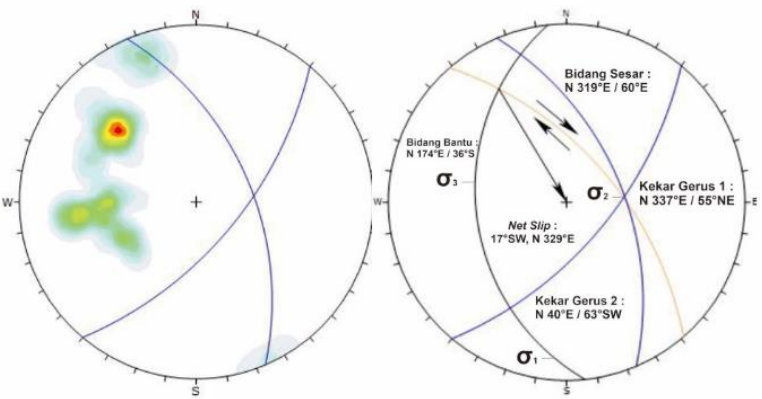

Gambar 7. Analisis kinematika sesar dan perhitungan kamb contour kekar gerus setiap sesar di daerah penelitian
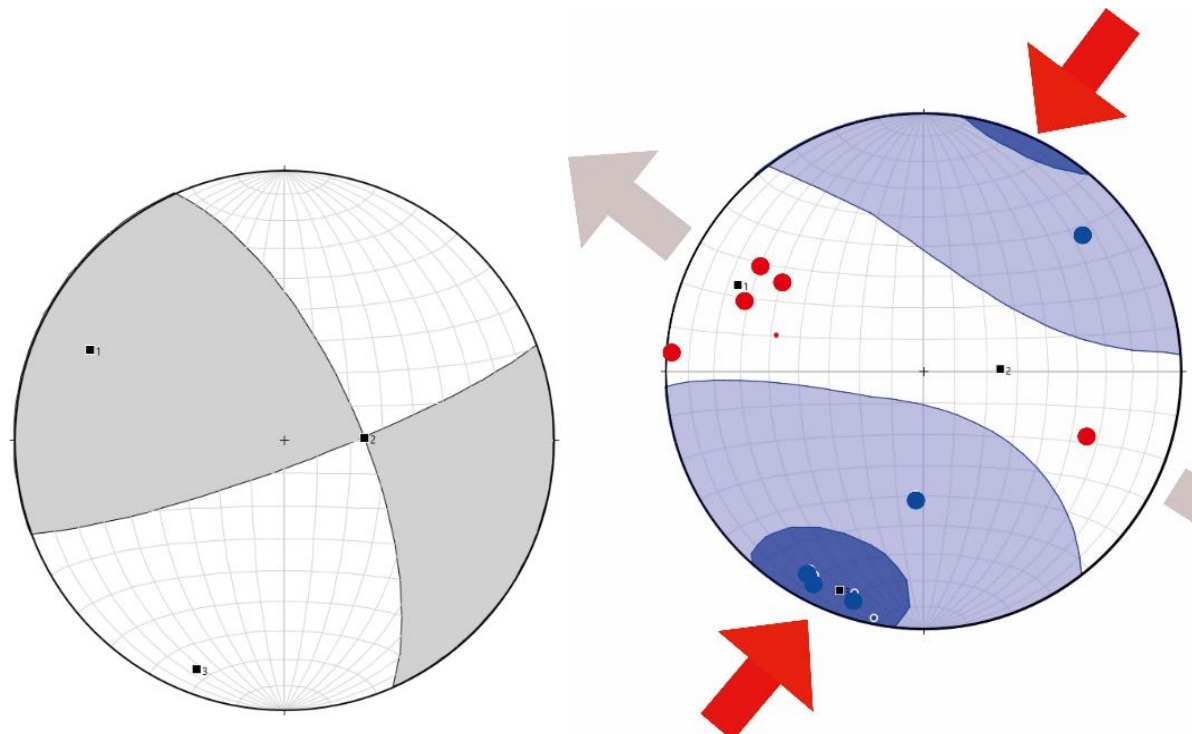

KETERANGAN

P-axis setiap sesar

T-axis setiap sesar

- Strain axis

Gambar 8. Analisis dinamik sesar di daerah penelitian dan kontur $P$-axis dan $T$-axis yang diolah dengan Faultkin 
Tabel 1. Perhitungan arah tegasan relatif seluruh sesar berdasarkan analisis kinematika

\begin{tabular}{|c|c|c|c|}
\hline Sesar & Kedudukan $\sigma 1$ & Kedudukan $\sigma 2$ & Kedudukan $\sigma 3$ \\
\hline F2 & $38^{\circ}, \mathrm{N} 001^{\circ} \mathrm{E}$ & $02^{\circ}, \mathrm{N} 268^{\circ} \mathrm{E}$ & $2^{\circ}, \mathrm{N} 281^{\circ} \mathrm{E}$ \\
\hline F3 & $04^{\circ}, \mathrm{N} 193^{\circ} \mathrm{E}$ & $60^{\circ}, \mathrm{N} 94^{\circ} \mathrm{E}$ & $28^{\circ}, \mathrm{N} 286^{\circ} \mathrm{E}$ \\
\hline F4 & $01^{\circ}, \mathrm{N} 182^{\circ} \mathrm{E}$ & $59^{\circ}, \mathrm{N} 89^{\circ} \mathrm{E}$ & $29^{\circ}, \mathrm{N} 274^{\circ} \mathrm{E}$ \\
\hline F1 & $50^{\circ}, \mathrm{N} 177^{\circ} \mathrm{E}$ & $38^{\circ}, \mathrm{N} 006^{\circ} \mathrm{E}$ & $3^{\circ}, \mathrm{N} 273^{\circ} \mathrm{E}$ \\
\hline F6 & $38^{\circ}, \mathrm{N} 001^{\circ} \mathrm{E}$ & $02^{\circ}, \mathrm{N} 268^{\circ} \mathrm{E}$ & $2^{\circ}, \mathrm{N} 281^{\circ} \mathrm{E}$ \\
\hline F5 & $44^{\circ}, \mathrm{N} 177^{\circ} \mathrm{E}$ & $46^{\circ}, \mathrm{N} 003^{\circ} \mathrm{E}$ & $03^{\circ}, \mathrm{N} 270^{\circ} \mathrm{E}$ \\
\hline F7 & $03^{\circ}, \mathrm{N} 178^{\circ} \mathrm{E}$ & $03^{\circ}, \mathrm{N} 178^{\circ} \mathrm{E}$ & $35^{\circ}, \mathrm{N} 270^{\circ} \mathrm{E}$ \\
\hline
\end{tabular}

\section{PEMBAHASAN}

Arah tegasan regional berarah relatif utara timurlaut-selatan baratdaya akan menghasilkan struktur bukaan berarah utara timurlaut-selatan baratdaya yang diduga dapat menjadi jalur permeabilitas yang baik bagi fluida hidrotermal. Keberadaan manifestasi air panas di daerah penelitian merupakan bukti jalur permeabilitas yang pembentukannya dikontrol oleh deformasi di daerah penelitian berupa sesar yang membuka dalam pergerakannya atau rekahan yang saling terhubung satu sama lain.

Analisis dinamik yang dilakukan pada masing-masing sesar menunjukkan kedudukan $P$-axis dan $T$-axis yang relatif seragam. Hal ini diinterpretasikan karena sesar yang terbentuk di daerah penelitian cenderung terbentuk pada arah tegasan kompresional relatif sama (Gambar 9).

Observasi lapangan memberikan konfirmasi keterdapatan zona hancuran struktur pada hasil analisis kelurusan dan lokasi anomali densitas kelurusan. Analisis kinematika dan dinamika sesar di daerah penelitian menyimpulkan bahwa arah tegasan utama relatif pada daerah penelitian berarah relatif utara timurlautselatan baratdaya. Arah tegasan utama tersebut relatif cocok dengan pengukuran GPS terdahulu yang menyatakan pergerakan relatif Blok Indo-Australia ke arah utara timurlaut (Kreemer dkk., 2000) dan penelitian regional terdahulu (Muraoka dkk., 2002). Arah dan pergerakan sesar di daerah penelitian sesuai dengan model struktur pure shear sebagaimana dipaparkan oleh Moody dan Hill (1956). Berdasarkan arah struktur dan pergerakannya, sesar F1, F2, F3, F4, F7, F8, F9, dan F10 di daerah penelitian diinterpretasikan sebagai sesar orde kesatu dan sesar F6 merupakan sesar orde ke dua dari sesar F1 (Gambar 10). Berdasarkan hasil analisis pengaruh struktur terhadap sistem panas bumi, maka dapat dilakukan analisis perangkingan sesar dengan mengacu pada parameter arah dan jenis sesar, keberadaan manifestasi, bukti keberadaan sesar, dan alterasi hidrotermal pada daerah penelitian, seperti yang terdapat pada Tabel 2 .

Berdasarkan Tabel 2, sesar F1 dan F2 dapat menjadi zona permeabel yang baik bagi jalur keluarnya fluida hidrotermal dari bawah permukaan. Selain itu, keberadaan manifestasi yang diduga berasosiasi dengan sesar F1 dan F2 dapat mengindikasikan adanya reservoir lapangan panas bumi Nage serta didukung oleh alterasi hidrotermal yang intensif di permukaan.

Indikasi keberadaan dua reservoir tersebut didasari dengan kemiringan sesar $\mathrm{F} 1$ yang berarah baratlaut dan sesar F2 yang relatif berada relatif jauh di sebelah barat $\mathrm{F} 1$ memiliki kemiringan berarah barat. Sesar F3 ditemukan terletak di antara sesar F1 dan F2 dan memiliki kemiringan berarah timur sehingga memisahkan kompartmen aliran fluida yang melalui sesar F1 dan F3 yang dimanifestasikan pada MAP Nage, serta aliran fluida yang melalui sesar F2 yang dimanifestasikan pada MAP Keli 1 dan Keli 2. Berdasarkan konfigurasi struktur dan perbedaan lokasi yang relatif jauh tersebut, dapat disimpulkan adanya indikasi keberadaan reservoir di bawah kemenerusan sesar F1 dan F3 serta sesar F2 (Gambar 11). 


\section{MAKALAH ILMIAH}

Sesar F10 merupakan sesar yang teridentifikasi dengan kelurusan kerucut sinder. Sesar ini diinterpretasikan hadir menjadi jalur naiknya gas hasil pendidihan fluida dari reservoir di bawah jajaran kerucut sinder yang keluar ke permukaan sebagai fumarola Wolo Puti. Reservoir yang menjadi sumber fluida hasil pendidihan pada fumarola Wolo Puti merupakan reservoir yang berbeda dengan reservoir dari fluida yang mengalir pada sesar F1 dan yang mengalir pada sesar F2
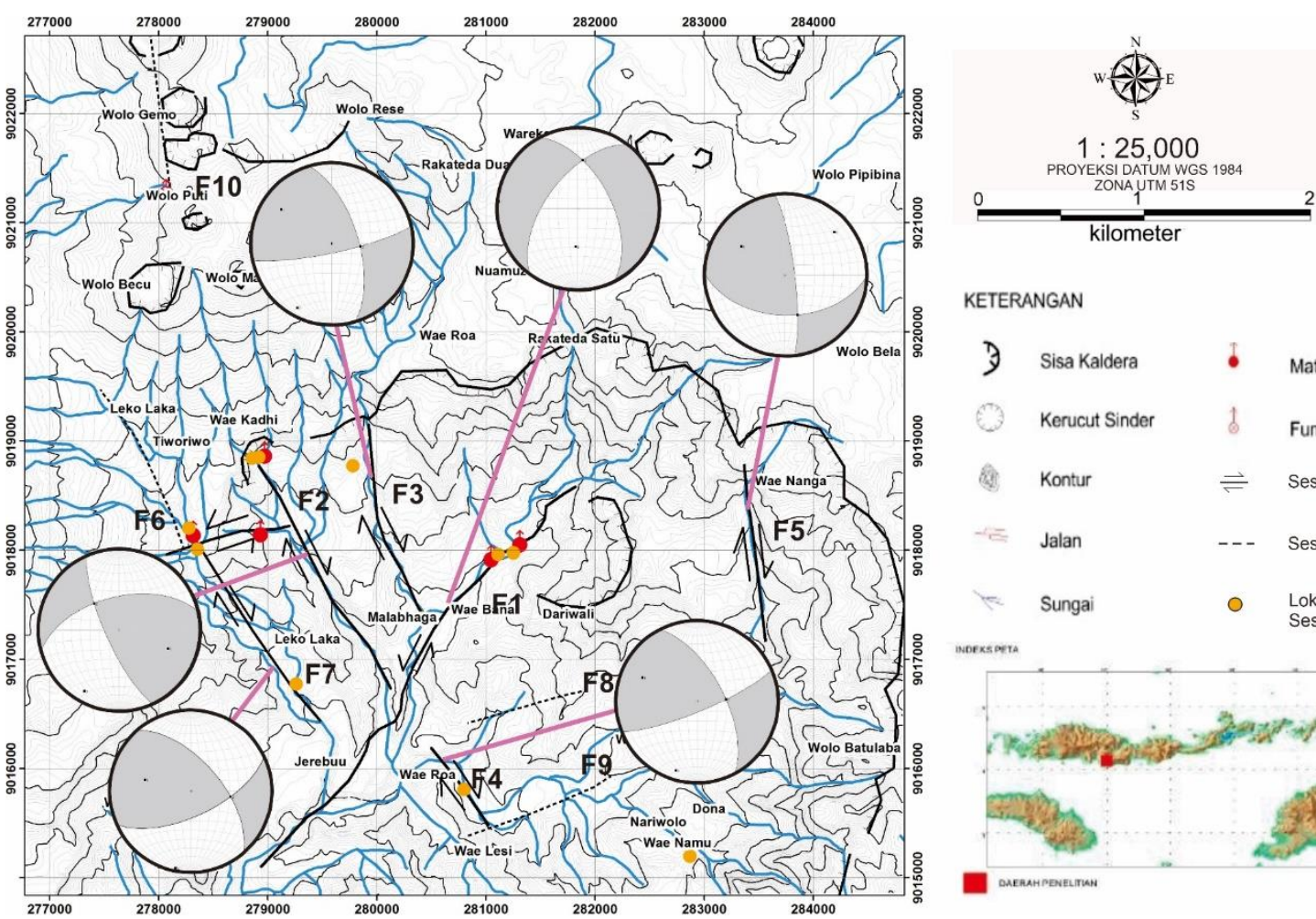

KETERANGAN

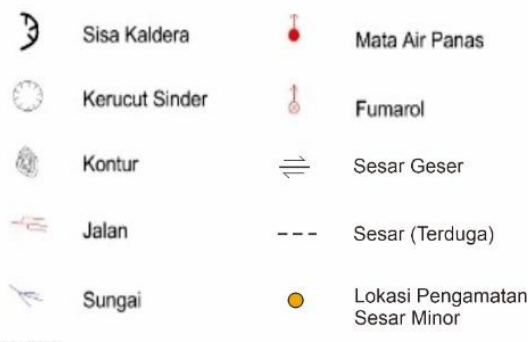

Gambar 9. Analisis dinamik masing-masing sesar di daerah penelitian menunjukkan $P$-axis dan $T$-axis relatif seragam.

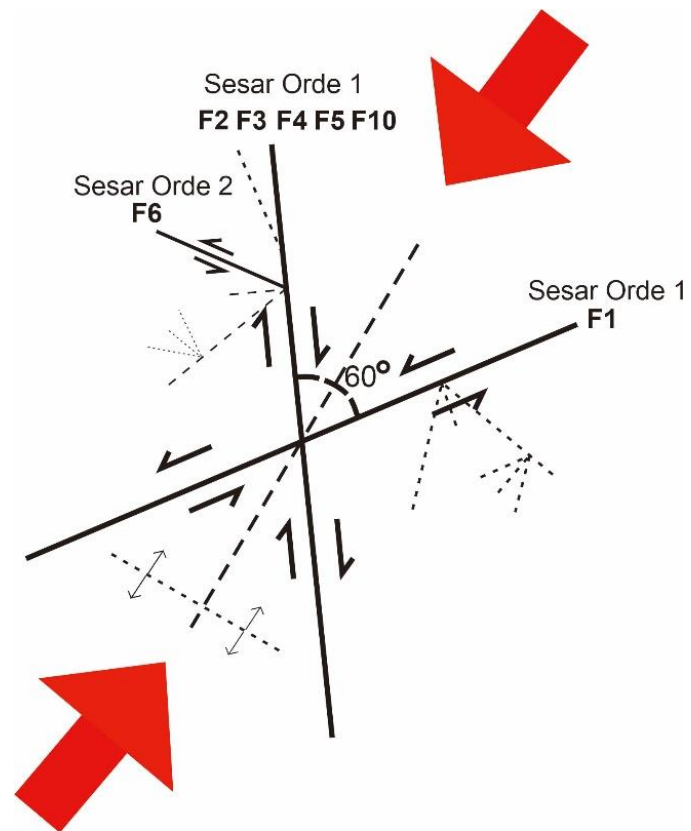

Gambar 10. Interpretasi struktur sesar daerah penelitian berdasarkan konsep pure shear

(Moody dan Hill, 1956) 


\section{MAKALAH ILMIAH}

Tabel 2. Perankingan sesar sebagai jalur keluarnya fluida hidrotermal sistem panas bumi lapangan Panas Bumi Nage

\begin{tabular}{|c|c|c|c|c|c|}
\hline RANKING & SESAR & $\begin{array}{c}\text { KRITERIA } 1 \\
\text { (Arah dan Jenis } \\
\text { Sesar) }\end{array}$ & $\begin{array}{c}\text { KRITERIA } 2 \\
\text { (Manifestasi) }\end{array}$ & $\begin{array}{l}\text { KRITERIA } 3 \\
\text { (Bukti Sesar) }\end{array}$ & $\begin{array}{c}\text { KRITERIA 4 } \\
\text { (Alterasi } \\
\text { Hidrotermal) }\end{array}$ \\
\hline 1 & $\mathrm{~F} 1$ & $\begin{array}{c}\text { TL-BD, sesar } \\
\text { geser }\end{array}$ & $\begin{array}{c}\text { Mata air panas } \\
\text { Nage } 1 \text { dan Nage } 2\end{array}$ & $\begin{array}{l}\text { Kelurusan citra } \\
\text { DEMNAS dan } \\
\text { sungai, depresi } \\
\text { topografi, struktur } \\
\text { penyerta yang } \\
\text { intensif }\end{array}$ & Intensif \\
\hline 2 & $\mathrm{~F} 2$ & $\begin{array}{l}\text { U BL-S TG, } \\
\text { sesar geser }\end{array}$ & $\begin{array}{c}\text { Mata air panas Keli } \\
1\end{array}$ & $\begin{array}{l}\text { Kelurusan citra } \\
\text { DEMNAS dan } \\
\text { sungai, depresi } \\
\text { topografi, struktur } \\
\text { penyerta yang } \\
\text { intensif }\end{array}$ & Intensif \\
\hline 3 & $\mathrm{~F} 7$ & $\begin{array}{l}\text { U BL- S TG, } \\
\text { sesar geser }\end{array}$ & $\begin{array}{l}\text { Mata air panas } \\
\text { Bena }\end{array}$ & $\begin{array}{l}\text { Kelurusan citra } \\
\text { DEMNAS dan } \\
\text { sungai, serta } \\
\text { struktur penyerta } \\
\text { yang intensif }\end{array}$ & - \\
\hline 4 & $\mathrm{~F} 6$ & $\begin{array}{l}\text { T TL- B BD, } \\
\text { sesar geser }\end{array}$ & $\begin{array}{l}\text { Mata air panas Keli } \\
2 \text { dan Bena }\end{array}$ & $\begin{array}{l}\text { Kelurusan citra } \\
\text { DEMNAS dan } \\
\text { sungai, serta } \\
\text { struktur penyerta } \\
\text { yang intensif }\end{array}$ & - \\
\hline 5 & F10 & $\begin{array}{c}\text { U BL-S TG, } \\
\text { sesar geser } \\
\text { (berdasarkan } \\
\text { pola pure shear) }\end{array}$ & Fumarol Wolo Puti & $\begin{array}{l}\text { Kelurusan citra } \\
\text { DEMNAS dan } \\
\text { sungai, depresi } \\
\text { topografi, dan } \\
\text { struktur penyerta } \\
\text { yang intensif }\end{array}$ & Intensif \\
\hline 6 & $\mathrm{~F} 4$ & $\begin{array}{l}\text { BL-TG, sesar } \\
\text { geser }\end{array}$ & $\begin{array}{l}\text { Rekahan kecil } \\
\text { mengeluarkan air } \\
\text { panas di sungai }\end{array}$ & $\begin{array}{l}\text { Kelurusan citra } \\
\text { DEMNAS dan } \\
\text { sungai, struktur } \\
\text { penyerta yang } \\
\text { intensif setempat }\end{array}$ & Setempat \\
\hline 7 & F3 & $\begin{array}{l}\text { U BL-S TG, } \\
\text { sesar geser }\end{array}$ & - & $\begin{array}{l}\text { Kelurusan citra } \\
\text { DEMNAS dan } \\
\text { sungai, struktur } \\
\text { penyerta yang } \\
\text { intensif }\end{array}$ & Intensif \\
\hline 8 & F5 & $\begin{array}{l}\text { U BL-S TG, } \\
\text { sesar geser }\end{array}$ & - & $\begin{array}{l}\text { Kelurusan citra } \\
\text { DEMNAS dan } \\
\text { sungai, depresi } \\
\text { topografi, dan } \\
\text { struktur penyerta } \\
\text { yang intensif }\end{array}$ & Intensif \\
\hline 9 & F8 & $\begin{array}{l}\text { U BL-S TG, } \\
\text { sesar geser }\end{array}$ & - & $\begin{array}{l}\text { Kelurusan citra } \\
\text { DEMNAS dan } \\
\text { sungai, depresi } \\
\text { topografi, dan } \\
\text { struktur penyerta } \\
\text { yang intensif }\end{array}$ & Intensif \\
\hline 10 & F9 & $\begin{array}{l}\text { U BL-S TG, } \\
\text { sesar geser }\end{array}$ & - & $\begin{array}{l}\text { Kelurusan citra } \\
\text { DEMNAS dan } \\
\text { sungai, depresi } \\
\text { topografi, dan } \\
\text { struktur penyerta } \\
\text { yang intensif }\end{array}$ & Intensif \\
\hline
\end{tabular}




\section{MAKALAH ILMIAH}

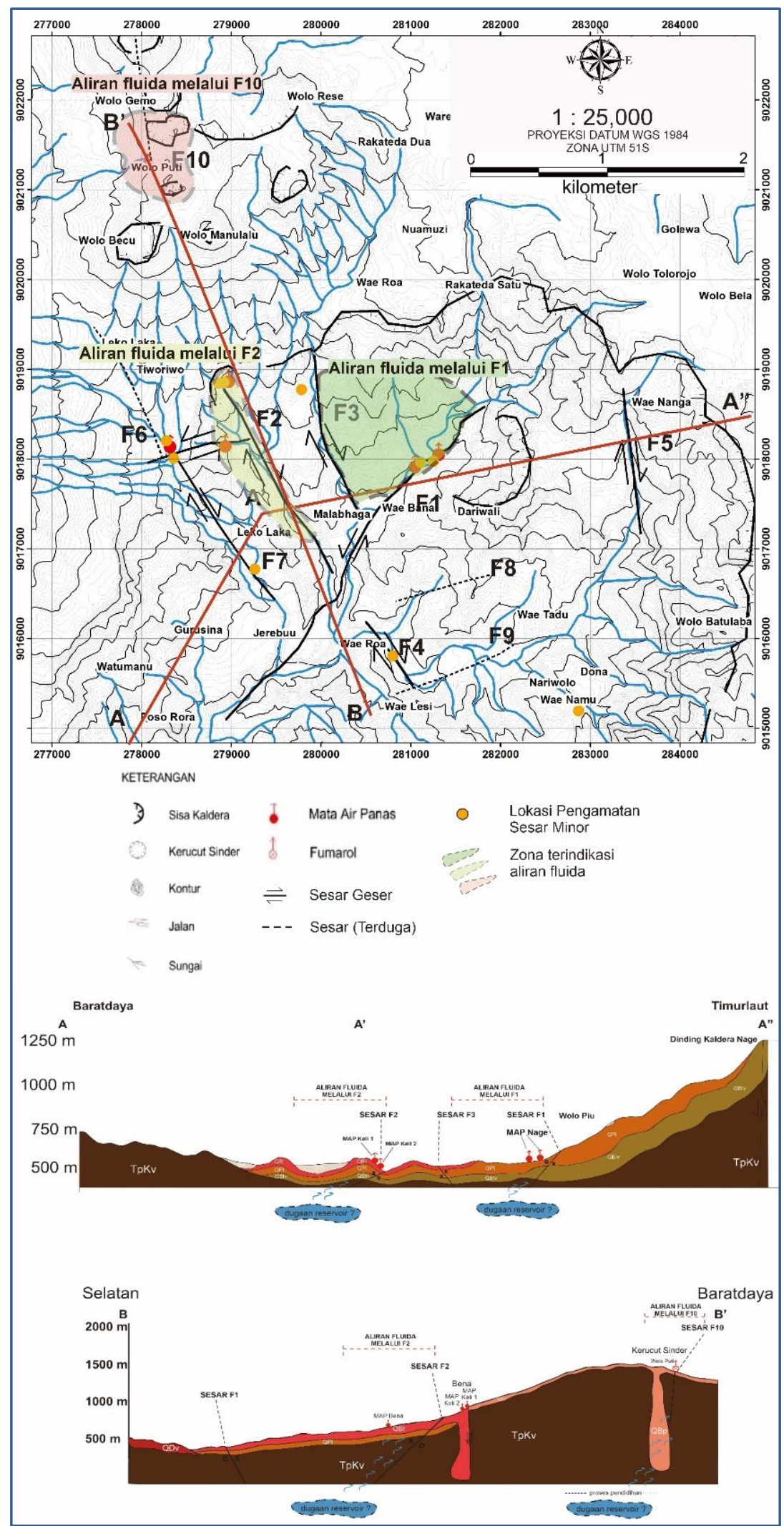

Gambar 11. Konfigurasi sesar pada daerah penelitian yang mengindikasikan aliran fluida yang melalui sesar F1 lalu dibatasi sesar F3, aliran fluida yang melalui sesar F2, dan aliran fluida hasil pendidihan yang melalui sesar F10 (kiri); dan penampang yang menggambarkan indikasi reservoir yang berbeda berdasarkan aliran fluida

(kanan; penampang dibuat berdasarkan peta dari Anonim, 2017) 


\section{KESIMPULAN}

Analisis struktur geologi, kelurusan citra DEMNAS, dan densitas kelurusan yang dilakukan di lapangan panas bumi Nage mengonfirmasi keterdapatan sesar-sesar geser yang terbentuk dari arah tegasan utama relatif berarah utara timurlautselatan baratdaya. Sesar-sesar di daerah penelitian diinterpretasikan sebagai sesar orde satu dan orde dua dari model pure shear. Beberapa sesar menjadi jalur keluarnya fluida hidrotermal pada lapangan panas bumi Nage yang dibuktikan dari kehadiran manifestasi panas bumi di sekitar zona hancuran sesar, serta alterasi hidrotermal dan struktur-struktur penyerta yang intensif. Keberadaan manifestasi panas bumi dan alterasi hidrotermal yang berasosiasi dengan sesar F1, F2, dan F10 tersebut mengindikasikan keterdapatan aliran fluida dari reservoir yang mengalir melalui $F 1$, aliran fluida yang melalui $F 2$, dan aliran fluida hasil pendidihan yang melalui F10. Ketiga aliran fluida yang melalui sesar tersebut secara geologi mencirikan keterdapatan tiga reservoir yang berbeda di lapangan panas bumi Nage.

\section{SARAN / REKOMENDASI}

Pembuktian peranan sesar-sesar di daerah penelitian terhadap sistem panas bumi yang berkembang dapat didukung dengan metode gaya berat dan divalidasi dengan pengeboran eksplorasi. Hal tersebut dapat dilakukan untuk membuktikan karakteristik sesar F1, F2, F7, F6, atau F10 yang menjadi fokus keberadaan permeabiltas yang terbentuk dari zona lemah, sehingga berfungsi sebagai media untuk jalur fluida hidrotermal pada sistem panas bumi Nage.

\section{UCAPAN TERIMA KASIH}

Penulis mengucapkan terima kasih kepada Tuhan Yang Maha Esa atas bimbinganNya dalam penulisan penelitian ini. Penelitian ini mendapatkan bantuan dari banyak pihak, yakni Pemerintah
Kabupaten Ngada dan masyarakat setempat.

\section{DAFTAR PUSTAKA}

Anonim, 2017. Laporan Survey Terpadu Daerah Panas Bumi Nage, Kabupaten Ngada, Provinsi Nusa Tenggara Timur, Pusat Sumber Daya Mineral Batubara dan Panas BumiBadan Geologi, Bandung.

Fauldz J.E., dan Hinz, N.H., 2015. Favorable tectonic and structural settings of geothermal systems in the Great Basin Region, western USA: proxies for discovering blind geothermal systems. Dalam Proceedings of the World Geothermal Congress 19-25 April 2015.

Fossen, H., 2016. Structural Geology : Second Edition. Cambridge University Press, 503 halaman.

Hamilton, W.B., 1979.Tectonics of the Indonesian region Vol. 1078, US Government Printing Office, Washington DC, 308 halaman.

Kamb, W.B., 1959. Ice petrofabric observations from Blue Glacier, Washington, in relation to theory and experiment. Journal of Geophysical Research, 64, 1891-1909.

Koesoemadinata, S., Noya, Y., dan Kadarisman, D. 1994. Peta Geologi Lembar Ruteng, Nusa Tenggara , Skala 1: 250,000, Pusat Penelitian dan Pengembangan Geologi, Bandung.

Kreemer, C., Holt, W.E., Goes, S., dan Govers, R., 2000. Active deformations in eastern Indonesia and Philippines from GPS and seismicity data, Journal of Geophysical Resources, 105, 663680.

Marett, R. dan Allmendinger, R.W., 1990. Kinematic analysis of fault-slip data. Journal of Structural Geology, 12, 973-986.

Moody, J.D. dan Hill, M.J., 1956. Wrenchfault tectonics, Geological Society of America Bulletin, 67(9), 1207-1246. 


\section{MAKALAH ILMIAH}

Muraoka, H., Nasution, A., Urai, M., Takahashi, M., Takashima, I., Simanjuntak, J., Sundhoro, $\mathrm{H}_{\text {., }}$ Aswin, D., Nanlohy, F., Sitorus, K., Takahashi, H., dan Koseki, T., 2002. Tectonic, volcanic and stratigraphic geology of the Bajawa geothermal field, central Flores, Indonesia, Bulletin of Geological Survey of Japan, 53(2/3), 109-138.
Pirajno, F., 2009. Hydrothermal Processes and Mineral Systems, Australia, Springer Science \& Business Media,.1243 halaman.

Sapiie, B., 2016. Kinematic analysis of fault-slip data in the Central Range of Papua, Indonesia. Indonesian Journal on Geoscience, 3(1), 1-16.

$\begin{array}{ll}\text { Diterima } & : 9 \text { September } 2021 \\ \text { Direvisi } & : 5 \text { Oktober } 2021 \\ \text { Disetujui } & : \text { 30 November } 2021\end{array}$


